\title{
HUBUNGAN STATUS GIZI DAN PERILAKU MASYARAKAT DENGAN KEJADIAN MALARIA DI WILAYAH KERJA PUSKESMAS KLASAMAN KOTA SORONG \\ ${ }^{1,2}$ Radeny ramdany, Elisabeth Samaran \\ ${ }^{1,2}$ Dosen Poltekkes Kemenkes Sorong Papua Barat \\ E-mail: Itjesamaran@gmail.com
}

\begin{abstract}
Malaria is an infectious disease caused by the parasitic genus Plasmodium which is transmitted by Anopheles mosquitoes. Until now, malaria is still a major global health problem because it often causes outbreaks, has a wide impact on quality of life and economy, and can result in death. The incidence of malaria in the population of Indonesia in 2013 decreased compared to 2007 but in West Papua has increased sharply. This places West Papua in the 3rd position with the highest malaria prevalence after Papua and East Nusa Tenggara and Sorong City being the regions with the highest number of malaria sufferers in West Papua Province. This study aims to determine the relationship of nutritional status and behavior of people to the incidence of malaria in the working area of Sorong City Health Center Klasaman. The research hypothesis is that nutritional status and community behavior are related to malaria incidence in the Sorong City Health Center working area.

This research was conducted in the working area of Sorong City Health Center Klasaman. This type of research is observational analytic with case-control study design. The independent variables are nutritional status, the use of mosquito nets, the use of anti-mosquito drugs, and the habit of being outside the house at night, while the dependent variable is the incidence of malaria. Samples are 144 malaria sufferers consisting of 72 cases and 72 controls. Cases were malaria patients while controls were not malaria patients, with matching according to age and sex. The sampling technique for the case group is simple random sampling and the control group is purposive sampling. Data collection was carried out by interview using a questionnaire and observations using a checklist. Bivariate statistical test uses Odds Ratio with $\alpha=0.05$.

The results showed that the nutritional status, the use of mosquito nets, the use of anti-mosquito drugs and the habit of being outdoors at night did not have a significant relationship to the incidence of malaria in the working area of Klasaman Health Center in Sorong City in 2016.

It is recommended for further researchers to conduct a broader study with a larger sample size so that it is known how much these variables affect the incidence of malaria
\end{abstract}

Keywords: Malaria, nutritional status, community behavior

\begin{abstract}
Abstrak
Malaria merupakan penyakit infeksi yang disebabkan oleh parasit Genus Plasmodium yang ditularkan oleh nyamuk Anopheles. Hingga saat ini malaria masih menjadi masalah kesehatan global yang utama karena sering menimbulkan KLB, berdampak luas terhadap kualitas hidup dan ekonomi, serta dapat mengakibatkan kematian. Insiden malaria pada penduduk Indonesia tahun 2013 menurun dibanding tahun 2007 tetapi di Papua Barat mengalami peningkatan tajam. Hal ini menempatkan Papua Barat di posisi ke-3 propinsi dengan prevalensi malaria tertinggi setelah Papua dan Nusa Tenggara Timur dan Kota Sorong menjadi daerahdengan jumlah penderita malaria tertinggi di Propinsi Papua Barat. Penelitian ini bertujuan untuk mengetahui hubungan status gizi dan perilaku masyarakat terhadap kejadian malaria di wilayah kerja Puskesmas Klasaman Kota Sorong.

Penelitian ini dilaksanakan di wilayah kerja Puskesmas Klasaman Kota Sorong. Jenis penelitian adalah observasional analitik dengan desain case-control study. Variabel independen adalah status gizi, penggunaan kelambu, penggunaan obat anti nyamuk, dan kebiasaan berada di luar rumah pada malam hari, sedangkan variabel dependen adalah kejadian malaria.Sampel adalah penderita malaria sebanyak 144 yang terdiri dari 72 kasus dan 72 kontrol. Kasus adalah penderita malaria sedangkan kontrol bukan penderita malaria, dengan matching menurut umur dan jenis kelamin. Teknik penarikan sampel untuk kelompok kasus yaitu simple random sampling dan kelompok kontrol yaitu purposive sampling. Pengumpulan data dilakukan dengan wawancara menggunakan kuesioner dan pengamatan menggunakan checklist. Uji statistik bivariat menggunakan Odds Ratio dengan $\alpha=0,05$.

Hasil penelitian menunjukkan bahwa status gizi, penggunaan kelambu, penggunaan obat anti nyamuk dan kebiasaan berada di luar rumah pada malam hari tidak memiliki hubungan yang bermakna terhadap kejadian malaria di wilayah kerja Puskesmas Klasaman Kota Sorong tahun 2016.

Disarankan bagi peneliti selanjutnya untuk melakukan penelitian yang lebih luas dengan jumlah sampel yang lebih besar agar diketahui seberapa besar variabel tersebutmempengaruhi kejadian malaria.
\end{abstract}

Kata Kunci : Malaria, status gizi, perilaku masyarakat 


\section{Pendahuluan}

Malaria merupakan penyakit infeksi yang disebabkan oleh parasit GenusPlasmodium yang ditularkan oleh nyamuk Anopheles. Infeksi malariamemberikan gejala berupa demam, menggigil, anemia dan ikterus (Harijanto, 2009). Hingga saat ini malaria masih menjadi masalah kesehatan global yang utama karena sering menimbulkan KLB, berdampak luas terhadap kualitas hidup dan ekonomi, serta dapat mengakibatkan kematian (Wijayanti, 2008).

WHO (World Health Organisation) menyebutkan hingga tahun 2005 malaria masihmenjadi masalah kesehatan utama di 107 negara. Penyakit ini menyerang sedikitnya 350500juta orang setiap tahunnya dan bertanggung jawab terhadap sekitar 1 juta kematian setiaptahunnya. Diperkirakan masih sekitar 3,2 miliar orang hidup di daerah endemis malaria (Wijayanti, 2008).

Hasil Riset Kesehatan Dasar Indonesia menunjukkan insiden malaria pada penduduk Indonesia tahun 2013 adalah 1,9 persen menurun dibanding tahun 2007 (2,9\%), tetapi di Papua Barat mengalami peningkatan tajam jumlah penderita malaria. Prevalensi malaria tahun 2013 adalah 6,0 persen. Lima propinsi dengan insiden dan prevalensi tertinggi adalah Papua $(9,8 \%$ dan $28,6 \%)$, disusul Nusa Tenggara Timur (6,8\% dan 23,3\%), Papua Barat (6,7\% dan 19,4\%), Sulawesi Tengah $(5,1 \%$ dan $12,5 \%)$, dan Maluku $(3,8 \%$ dan $10,7 \%$ ). Dari 33 propinsi di Indonesia, 15 propinsi mempunyai prevalensi malaria di atas angka nasional, sebagian besar berada di Indonesia Timur (Depkes RI, 2013).

Dari 579 kabupaten/kota di Indonesia, jumlah kabupaten/kota endemistahun 2004 sebanyak 424 dengan perkiraan persentase penduduk yang berisiko tertular sebesar 42,42\% (Ferdinan J, dkk, 2009). Data Riset Kesehatan Dasar tahun 2007 menyebutkan dari 33 propinsi, propinsi Papua Barat merupakan propinsi dengan nilai proporsi tertinggi daerah endemis perkembangbiakan vektor penyakit Malaria (Depkes RI, 2017).

Kota Sorongmerupakan daerah yang mempunyai jumlah penderita malaria tertinggi di Propinsi Papua Barat. Menurut data Dinas Kesehatan Kota Sorong, selama bulan JanuariDesember 2014 tercatat terdapat 7.617 penderita malaria dengan pengklasifikasian 3 golongan umur, yaitu: umur 0-4 tahun sebanyak 2.426 orang, umur 5-14 tahun sebanyak 1.603 orang, $>15$ tahun sebanyak 3.588 orang (Dinkes Kota Sorong, 2015).

Data dari Puskesmas Klasaman menunjukkan jumlah penderita penyakit malaria semakin meningkat dari tahun ke tahun, yaitu pada bulan Januari-Desember 2014 sebanyak
1.521 kasus dan bulan Januari-Desember 2015 meningkat menjadi 3.164 kasus.

Kejadian malaria dipengaruhi oleh beberapa faktor, yaitu host (manusia dan nyamuk),agent (parasit/plasmodium), dan environment (lingkungan). Malnutrisi bertanggung jawab pada lebih dari $50 \%$ angka kematian tiap tahun di negara berkembang.Dalam berbagai derajat, malnutrisi meningkatkan risiko terhadap penyakit infeksi dan angka kematian akibat penyakit infeksi tersebut (Harohalli, 2006). Demikian juga dengan perilaku masyarakat yang menunjang interaksi antara manusia dan nyamuk malaria sehingga transmisi penyakit dapat lebih mudah terjadi (Saikhu, 2011).

Berdasarkan latar belakang tersebut, maka penulis tertarik untuk mengetahui lebih jauh mengenai hubungan status gizi dan perilaku masyarakat dengan kejadian malaria di Wilayah Kerja Puskesmas Klasaman Kota Sorong.

\section{Bahan dan Metode}

Jenis Penelitian

Jenis penelitian yang digunakan adalah penelitian observational analitik, dengan pendekatan case-control study, yaitu suatu rancangan yang membandingkan kelompok individu dengan penyakit tertentu (kasus) dengan kelompok individu yang bebas dari penyakit (kontrol). Kemudian dilakukan penelusuran secara retrospektif terhadap variabel independen (faktor risiko).

\section{Lokasi dan WaktuPenelitian}

Penelitian ini dilaksanakan padabulan November-Desember 2016 di wilayah kerja Puskesmas Klasaman Kota Sorong.

\section{Pengumpulan dan Analisis Data}

Pengumpulan data dilakukan dengan wawancara langsung terhadap responden dengan menggunakan kuesioner,pengukuran berat badan menggunakan timbangan, dan pengukuran tinggi badan menggunakan microtoise.Analisis data dilakukan dengan menggunakan uji statistik Odds Ratio (OR).

\section{Populasi dan Sampel}

\section{Polpulasi}

Populasi pada penelitian ini adalah seluruh pasien yang berobat dan terdata di buku register di Puseksmas Klasaman Kota Sorong selama tahun 2016.

Sampel

Sampelkasus adalah pasien penderita malaria, sedangkan kontrol adalah pasien yang bukan penderita malaria. 


\section{Metode Pengambilan Sampel}

Pengambilan sampel kasus dilakukan dengan teknik purposive samplingsedangkan untuk kelompok kasus menggunakan metode

Tabel 1 berisi hasil analisis faktor risiko untuk keempat variebel independen yang diteliti. Adapun hasil perhitungan Odds Ratio (OR) untuk setiap variabel sebagai berikut :

1. Status Gizi

Untuk variabel status gizi diperoleh nilai OR $=1,136$ CI 95\% (0,564-2,291). Oleh karena nilai Lower Limit dan Upper Limit mencakup nilai satu maka hasil uji tersebut dinyatakan tidak bermakna. Dengan demikiansStatus gizi tidak memiliki hubungan yang bermakna terhadap kejadian malaria di wilayah kerja Puskesmas Klasaman Kota Sorong.

\section{Pengunaan kelambu}

Untuk variabel pengunaan kelambu diperoleh nilai OR $=1,690$ CI 95\% $(0,680$ 4,198). Oleh karena nilai Lower Limit dan Upper Limit mencakup nilai satu maka hasil uji tersebut dinyatakan tidak bermakna. Dengan demikian penggunaan kelambu pada waktu tidur tidak memiliki hubungan yang bermakna terhadap kejadian malariapada pasien di Wilayah Kerja Puskesmas Klasaman Kota Sorong.

\section{Penggunaan Obat Anti Nyamuk}

Untuk variabel penggunaan obat anti nyamuk diperoleh nilai OR $=1,486$ CI 95\% (0,767-2,881). Oleh karena nilai Lower Limit dan Upper Limit mencakup nilai satu maka hasil uji tersebut dinyatakan tidak bermakna. Dengan demikian dapat dikatakan bahwa penggunaan obat anti nyamuktidak memiliki hubungan yang tidak bermakna terhadap kejadian malaria di wilayah kerja Puskesmas Klasaman Kota Sorong 4. Kebiasaan Berada di Luar Rumah Pada Malam Hari

Untuk variabel kebiasaan berada di luar rumah pada malam haridiperoleh nilai OR = 1,923 CI 95\% (0,859-4,307). Oleh karena nilai Lower Limit dan Upper Limit mencakup nilai satu maka hasil uji tersebut dinyatakan tidak bermakna. Dengan demikian dapat dikatakan bahwa kebiasaan berada di luar rumah pada malam haritidak memiliki hubungan yang bermakna terhadap kejadian malariapada pasien di wilayah kerja Puskesmas Klasaman Kota Sorong.

\section{Pembahasan}

\section{Status Gizi}

Status gizi berhubungan dengan kejadian malaria oleh karena kerentanan sistem imun. Malnutrisi dapat mengubah respon imun. Jumlah simple random sampling,. Jumlah sampel masing-masing 72 kasus dan 72 kontrol dengan perbandingan 1:1, sehingga jumlah keseluruhan sampel sebanyak $144 \quad$ orang

\section{Hasil Penelitian}

limfosit $\mathrm{T}$ akan berkurang, respon limfosit tidak memadai (impaired lymphocyte response), beberapa jenis sitokin dan komplemen akan menurun jumlahnya mengakibatkan respon fagositosis menurun. Sekresi IgA dilaporkan juga mengalami infeksi atau jatuh ke dalam keadaan infeksi yang berat atau kronis (Harohalli RS, 2006).

Depkes (2012) menyebutkan bahwa anak-anak (0-15 tahun) lebih rentan terhadap infeksi parasit malaria, terutama pada anak gizi buruk. Infeksi akan berlangsung lebih hebat pada usia muda atau sangat muda karena belum matangnya sistem imun, sedangkan pada usia tua disebabkan oleh penurunan daya tahan tubuh misalnya oleh karena penyakit penyerta.

Hasil uji statistik yang dilakukan dalam penelitian ini diperoleh Odds Ratiostatus gizisebesar 1,136 kali dengan nilai Lower Limit dan Upper Limit sebesar0,564 dan 2,291. Dengan demikian dapat dikatakan bahwa hasil uji statistik Odds Ratio terhadap penelitian ini tidak memiliki hubungan yang bermakna dengan kejadian malaria.

Hasil uji statistik ini tidak sejalan dengan penelitian yang dilakukan oleh Rice et al (2007) yang mengatakan terdapat hubungan yang kuat antara malnutrisi dalam hal meningkatkan risiko kematian pada penyakit infeksi termasuk malaria pada anak-anak di negara berkembang. Penelitian lain oleh Shanker yang menguji hubungan antara malaria dan status gizi menunjukkan bahwa malnutrisi protein dan energi mempunyai hubungan dengan morbiditas dan mortalitas pada berbagai malaria. Penelitian yang dilakukan oleh Suwadera (2010) juga menunjukkan bahwa balita dengan status gizi kurang berisiko lebih rentan menderita malaria1,86 kali dibandingkan dengan yang berstatus gizi baik.

\section{Pengunaan Kelambu}

Kelambu merupakan alat yang telah digunakan sejak dahulu kala. Sesuai persyaratan Depkes RI kelambu yang baik yaitu memiliki jumlah lubang per $\mathrm{cm}$ antara 6-8 dengan diameter 1,2-1,5 mm. Ada dua jenis kelambu yang sering digunakan masyarakat yaitu kelambu yang tidak menggunakan insektisida dan kelambu yang dicelup dengan insektisida (Arsin, 2012).

$$
\text { WHO telah menganjurkan }
$$
pengembangan metode alternatif pemberantasan 
vektor malaria yang lebih efisien dari penyemprotan, yaitu dengan penggunaan kelambu berinsektisida permetrin. Permetrin adalah insektisida sintetik yang bekerja secara kontak langsung atau lewat saluran pencernaan. Pemakaian dosis rendah yang diresapkan pada kelambu sangat baik untuk membunuh nyamuk dan tidak berbahaya bagi manusia (Arsin, 2012).

Hasil uji statistik yang dilakukan dalam penelitian ini diperoleh Odds Ratiopenggunaan kelambu pada waktu tidur sebesar 1,690 kali dengan nilai Lower Limit dan Upper Limit0,680 dan 4,198. Dengan demikian dapat dikatakan bahwa hasil uji statistik Odds Ratio terhadap penelitian ini tidak memiliki hubungan yang bermakna terhadap kejadian malaria.

Hasil uji statistik ini tidak sejalan dengan penelitian yang dilakukan oleh Nasir (2011) di Halmahera Timur yang menemukan adanya hubungan yang signifikan antara pemakaian kelambu berinsektisida dengan kejadian malaria. Semakin sering pemakaian kelambu berinsektisida, semakin rendah risiko kejadian malaria.

\section{Pengunaan Obat Anti Nyamuk}

Berbagai usaha yang dapat dilakukan untuk mengurangi kejadian malaria diantaranya yaitu dengan menggunakan obat anti nyamuk pada malam hari baik obat nyamuk bakar (fumigan), obat nyamuk semprot (aerosol), obat nyamuk listrik (elektrik) maupun zat penolak nyamuk (repellent) (Arsin, 2012).

Hasil uji statistik yang dilakukan dalam penelitian ini diperoleh Odds Ratio konsumsi alkohol sebesar 1,486 kali dengan nilai Lower Limit dan Upper Limit0,767 dan 2,881. Oleh karena nilai Lower Limit dan Upper Limit mencakup nilai satu maka dapat dikatakan bahwa hasil uji statistik Odds Ratio terhadap penelitian ini memiliki hubungan yang tidak bermakna terhadap kejadian malaria.

Hasil penelitian ini tidak sejalan dengan penelitian oleh Husin (2007) yang menyebutkan bahwa orang yang tidur tanpa menggunakan obat anti nyamuk mempunyai risiko terjadinya malaria 3,43 kali lebih besar dibandingkan dengan orang yang menggunakan obat anti nyamuk.

\section{Kebiasaan Berada di Luar Rumah pada Malam Hari}

Kebiasaan manusia untuk berada di luar rumah sampai larut malam akan memudahkan tergigit oleh nyamuk, karena sifat vektor yang eksofilik (senang tinggal di luar rumah) dan eksofagik (suka menggigit di luar rumah) untuk manusia yang terbiasa berada di luar rumah sampai larut malam akan mudah digigit oleh nyamuk (Arsin, 2012).
Perilaku nyamuk Anopheles dalam mencari darah (feeding place) terbagi berdasarkan spesies yaitu ada nyamuk yang aktif menggigit mulai senja hari hingga menjelang tengah malam dan ada nyamuk yang aktif menggigit mulai tengah malam sampai pagi hari sehingga aktifitas menggigit nyamuk Anopheles selalu aktif sepanjang malam, mulai pukul 18.00 hingga 06.00 (Arsin, 2012).

Hasil uji statistik yang dilakukan dalam penelitian ini diperoleh Odds Ratiokebiasaan berada di luar rumah pada malam hari sebesar 1,923 kali dengan nilai Lower Limit dan Upper Limit0,859 dan 4,307. Oleh karena nilai Lower Limit dan Upper Limit mencakup nilai satu maka dapat dikatakan bahwa hasil uji statistik Odds Ratio terhadap penelitian ini memiliki hubungan yang tidak bermakna terhadap kejadian malaria.

Hasil uji statistik ini tidak sejalan dengan penelitian yang dilakukan oleh Nurfitrianah (2013) yang menemukan bahwa orang yang mempunyai kebiasaan di luar rumah pada malam hari tanpa memakai pakaian pelindung mempunyai risiko 2,4 kali untuk terkena malaria daripada orang yang tidak punya kebiasaan di luar rumah pada malam hari.

\section{Kesimpulan}

Berdasarkan penelitian yang dilakukan, maka dapat ditarik kesimpulan sebagai berikut:

1. Status gizimemiliki hubungan yang tidak bermakna terhadap kejadian malaria di wilayah kerja Puskesmas Klasaman Kota Sorong.

2. Penggunaan kelambu memiliki hubungan yang tidak bermakna terhadap kejadian malaria di wilayah kerja Puskesmas Klasaman Kota Sorong.

3. Penggunaan obat anti nyamuk memiliki hubungan yang tidak bermakna terhadap kejadian malaria di wilayah kerja Puskesmas Klasaman Kota Sorong.

4. Kebiasaan berada di luar rumah pada malam hari memiliki hubungan yang tidak bermakna terhadap kejadian malaria di wilayah kerja Puskesmas Klasaman Kota Sorong.

\section{Saran}

1. Seluruh variabel independen pada penelitian ini memang dinyatakan tidak bermakna tetapi masih perlu dilakukan penelitian yang lebih luasdengan jumlah sampel yang lebih besar agar diketahui seberapa besar variable tersebut mempengaruhi kejadian malaria, karena seperti yang kita ketahui bahwa penyakit malaria merupakan interaksi dari berbagai faktor yang berhubungan dengan status gizi dan perilaku termasuk penggunaan kelambu, obat anti nyamuk dan 
kebiasaan berada di luar rumah pada malam hari.

2. Penyuluhan yang lebih intensif dari aparat terkait mengenai faktor-faktor yang berhubungan dengan kejadian malaria agar masyarakat dapat melakukan upaya pencegahan sehingga angka morbiditas dan mortalitas malaria dapat diminimalisir.

\section{Ucapan terima kasih}

Rasa terima kasih tak lupa penulis haturkan kepada pihak Puskesmas Klasaman Kota Sorong dan semua pihak yang telah membantu selama penelitian berlangsung.

\section{Daftar Pustaka}

Arsin, A. Arsunan. 2012. Malaria di Indonesia, Tinjauan Aspek Epidemiologi. Masagena Press. Makassar.

Departemen Kesehatan RI. 2013. Riset Penelitian Dasar (RISKESDAS). Badan Penelitian dan Pengembangan Kesehatan. Depkes RI. Jakarta.

Departemen Kesehatan RI. 2017. Riset Penelitian Dasar (RISKESDAS). Badan Penelitian dan Pengembangan Kesehatan. Depkes RI. Jakarta.

Depkes RI. 2008. Pedoman Penatalaksanaan Kasus Malaria di Indonesia. Direktorat Jenderal P2PL, Depkes RI. Jakarta.

Depkes RI. 2012. Pedoman Penatalaksanaan Kasus Malaria di Indonesia. Direktorat Jenderal P2PL, Depkes RI. Jakarta.

Dinas Kesehatan Kota Soron. 2015. Profil Kesehatan Kota Sorong. Dinas Kesehatan Kota Sorong. Sorong.

Ferdinand J, dkk. 2009. Situasi Malaria di Indonesia dan Penanggulangannya. EGC. Jakarta.

Harijanto, P.N, dkk. 2009. Malaria : dari Molekuler ke Klinis. Ed.2. EGC. Jakarta.

Harohalli RS, Donna GG. Malnutrition. 2006. Diunduh

dari http://www.emedicine.medscape.comlartic le/985140-overview. Diakses pada 17 Agustus 2016.

Hasyim, Hamzah, dkk. 2014. Determinan Kejadian Malaria di Wilayah Endemis.Jurnal Kesehatan Masyarakat Nasional Vol. 8, No. 7, Februari 2014.

Husin, Hasan. 2007. Analisis Faktor Risiko Kejadian Malaria Di Puskesmas Sukamerindu Kecamatan Sungai Serut Kota Bengkulu Propinsi Bengkulu. Tesis. Program Pascasarjana Universitas Diponegoro. Semarang.

Nasir, Muhammad. 2011. Hubungan Penggunaan Kelambu Berinsektisida dengan kejadian Malaria di Kabupaten Halmahera Timur.
Tesis. Konsentrasi Epidemiologi Program Pascasarjana Universitas Hasanuddin. Makassar.

Prabowo, Arlan. 2008. Malaria Mencegah dan Mengatasinya. Puspa Swara. Jakarta.

Rice, Tallud P, Andaman. 2007. Interactive Resource For The Rational Selection And Comparison of Putative Drug Target Proteins In Malaria. Malaria Journal 8(5): 12-18.

Saikhu. 2011. Faktor resiko lingkungan dan perilaku yang mempengaruhi kejadian kesakitan malaria di Propinsi Sumatera. Tesis. Universitas Sumatera Utara.

Suwadera. 2010. Analisis Hubungan Antara Kondisi Ventilasi, Kepadatan Hunian, Kelembaban Udara, Suhu, Dan Pencahayaan Alami Rumah Dengan Kajadian Malaria Di Wilayah Kerja Puskesmas Wara Utara Kota Palopo. Jurnal FKM Universitas Samratulangi 2(2): 5-8.

Wijayanti K. 2008. Penyakit-penyakit yang Meningkat Kasusnya Akibat Perubahan Iklim Global. Pusat Penelitian dan Pengembangan dan Kebijakan Kesehatan. Depkes

RI

Jakarta. 
Tabel 1

Faktor Yang Berhubungan Dengan Kejadian Malaria di Wilayah Kerja Puskesmas Klasaman Kota Sorong Tahun 2016

\begin{tabular}{|c|c|c|c|c|c|c|c|c|c|}
\hline \multirow[t]{2}{*}{ Variabel } & \multirow[t]{2}{*}{ Kategori } & \multicolumn{2}{|c|}{$\begin{array}{l}\text { Malaria } \\
\text { (Kasus) }\end{array}$} & \multicolumn{2}{|c|}{$\begin{array}{c}\text { Bukan } \\
\text { Malaria } \\
\text { (Kontrol) }\end{array}$} & \multicolumn{2}{|c|}{ Jumlah } & \multirow[t]{2}{*}{ OR } & \multirow{2}{*}{$\begin{array}{c}\text { CI }(95 \%) \\
\text { LL-UL }\end{array}$} \\
\hline & & $\mathrm{n}$ & $\%$ & $\mathrm{~N}$ & $\%$ & $\mathrm{n}$ & $\%$ & & \\
\hline \multirow[b]{2}{*}{ Status Gizi } & Risiko Tinggi & 24 & 33,3 & 22 & 30,6 & 46 & 31,9 & 1,136 & \multirow[t]{2}{*}{$\begin{array}{l}0,564- \\
2,291\end{array}$} \\
\hline & Risiko Rendah & 48 & 66,7 & 50 & 69,4 & 98 & 68,1 & & \\
\hline \multirow{2}{*}{$\begin{array}{c}\text { Pengunaan } \\
\text { Kelambu }\end{array}$} & Risiko Tinggi & 63 & 87,5 & 58 & 80,6 & 121 & 84,0 & 1,690 & \multirow[t]{2}{*}{$\begin{array}{c}0,680- \\
4,198\end{array}$} \\
\hline & Risiko Rendah & 9 & 12,5 & 14 & 19,4 & 23 & 16,0 & & \\
\hline \multirow{2}{*}{$\begin{array}{l}\text { Penggunaan } \\
\text { Obat Anti } \\
\text { Nyamuk }\end{array}$} & Risiko Tinggi & 44 & 61,1 & 37 & 51,4 & 81 & 56,2 & 1,486 & \multirow[t]{2}{*}{$\begin{array}{c}0,767- \\
2,881\end{array}$} \\
\hline & Risiko Rendah & 28 & 38,9 & 35 & 48,6 & 63 & 43,8 & & \\
\hline \multirow{2}{*}{$\begin{array}{l}\text { Kebiasaan } \\
\text { Berada di Luar } \\
\text { Rumah Pada } \\
\text { Malam Hari }\end{array}$} & Risiko Tinggi & 20 & 27,8 & 12 & 16,7 & 32 & 22,2 & 1,923 & \multirow[t]{2}{*}{$\begin{array}{c}0,859- \\
4,307\end{array}$} \\
\hline & Risiko Rendah & 52 & 72,2 & 60 & 83,3 & 112 & 77,8 & & \\
\hline
\end{tabular}

